\title{
Evaluation of the Effect of Sleep Habits of 0-2 Years Age Children on the Quality of Mother's Life
}

\author{
Aysel Topan (Corresponding author) \\ Department of Nursing, Faculty of Health Sciences, Zonguldak Bulent Ecevit University \\ 67600 Kozlu, Zonguldak, Turkey \\ E-mail: ayskose@hotmail.com \\ Tulay Kuzlu Ayyildiz \\ Department of Nursing, Faculty of Health Sciences, Zonguldak Bulent Ecevit University \\ 67600 Kozlu, Zonguldak, Turkey \\ E-mail: tayyildiz67@hotmail.com \\ Muge Seval \\ Department of Nursing, Faculty of Health Sciences, Zonguldak Bulent Ecevit University \\ 67600 Kozlu, Zonguldak, Turkey \\ E-mail: sevalmuge@gmail.com \\ Aylin Kurt \\ Department of Nursing, Faculty of Health Sciences, Zonguldak Bulent Ecevit University \\ 67600 Kozlu, Zonguldak, Turkey \\ E-mail: aylinkurt67@gmail.com \\ Ozlem Ozturk Sahin \\ Department of Nursing, Faculty of Health Sciences, Karabuk University \\ Karabuk, Turkey \\ E-mail: zlemzturk@hotmail.com \\ Birsen Mutlu \\ Faculty of Health Sciences, Istanbul University, Istanbul, Turkey \\ E-mail: birsenmutlu34@hotmail.com \\ Ayla Gundogdu \\ Department of Nursing, Faculty of Health Sciences, Zonguldak Bulent Ecevit University \\ 67600 Kozlu, Zonguldak, Turkey \\ E-mail: aylagndgdu@hotmail.com
}

\begin{abstract}
The aim of this study was to determine the sleep habits of $0-2$ year old children, the methods used by mothers to put their children to sleep and the effects of sleep patterns on the quality of life of the mothers. The study was descriptive and cross-sectional and carried out at the family health centers in Zonguldak between February 2015 and May 2015. The sample of this research consists of 200 mothers of the children 0-2 years old. These volunteer mothers applied to the family health centers including in this research. The data was collected by a survey used to determine the sleep habits of children aged 0-2 year old and to determine the methods used by mothers for putting their children to sleep, and the short form (SF)-36 quality of life scale. It was found that $35 \%$ of the mothers in the study between $18-25$ years of age and $25 \%$ of the children of the mothers were 2-6 months old, $7 \%$ of the children had night sleep as irregular, $33.5 \%$ of mothers shook their

Page | 298

www.iiste.org
\end{abstract}


child by standing and $46 \%$ of the mothers stated that the sleep quality of the mothers negatively affected the quality of life. The mothers received the lowest score $(25.33 \pm 2.05)$ from the sub-dimension of quality of life, while the highest score was obtained from physical function $(74.65 \pm 23.6)$. It was found that the child's sleep patterns affected the quality of life of the mothers in many areas, and the types of the child sleeps especially affected the mother in her mental role.

Keywords: Mother, Child, Sleep habits, Quality of life

DOI: $10.7176 / \mathrm{JSTR} / 5-2-36$

\title{
0-2 Yaş Grubu Çocukların Uyku Alışkanlıklarının Annelerin Yaşam Kalitesi Üzerine Etkisinin Değerlendirilmesi
}

\begin{abstract}
Özet
$\mathrm{Bu}$ çalışma, 0-2 yaş çocukların uyku alışkanlıklarını saptamak, annelerin çocuklarını uyutmak için başvurdukları yöntemleri ve çocukların uyku düzeninin annelerin yaşam kalitelerine olan etkisini belirlemek amacı ile yapılmıştır. Araştırma, tanımlayıcı ve kesitsel tipte olup, Şubat 2015-Mayıs 2015 tarihleri arasında Zonguldak il merkezinde bulunan aile sağlığı merkezlerinde gerçekleştirilmiştir. Araştırmanın örneklemini belirlenen aile sağlığı merkezlerine araştırmanın yapıldığı tarihlerde $0-2$ yaş çocuğu olan ve araştırmaya katılmayı kabul eden 200 anne oluşturmuştur. Veri toplama aracı olarak, 0-2 yaş çocukların uyku alışkanlıklarını saptamak ve annelerin çocuklarını uyutmak için başvurdukları yöntemleri belirlemek için oluşturulan anket formu ile yaşam kalitelerini değerlendirmek için SF 36 Yaşam Kalitesi Ölçeği kullanılmıştır. Araştırmaya katılan annelerin \%35'inin 18-25 yaş arasında ve annelerin çocuklarının \%25'inin 2-6 aylık olduğu, çocukların \%37'sinin gece uykusunun düzensiz olduğu, annelerin \%33.5' inin çocuğunu ayakta sallayarak uyuttuğu ve annelerin \%46's1 çocuğun uyku düzeninin yaşam kalitesini olumsuz etkilediğini ifade ettiği saptanmıştır. Araştırmaya katılan anneler, yaşam kalitesi ölçeğinin, ağrı alt boyutundan en düşük $(25.33 \pm 2.05)$ puanı alırken, fiziksel işlev (74.65 \pm 23.6$)$ alt boyutundan en yüksek puanı aldığ1 belirlenmiş̧ir. Çocuğun uyku düzeninin annenin yaşam kalitesini birçok alanda, çocuğu uyutma şeklinin ise özellikle anneyi mental rol alanında etkilediği saptanmıştır.
\end{abstract}

Anahtar kelimeler: Anne, çocuk, Uyku alışkanlığı, Yaşam kalitesi

\section{Giriș}

Uyku beslenme gibi doğal bir gereksinim ve beyin tarafindan programlanan nörofizyolojik bir durumdur. Uyku, günlük yaşantımızı, fiziksel ve psikolojik sağlığımızı birçok açıdan etkileyen ve bebeklerin temel gereksinimlerinden biridir. Uyku ihtiyacı, içinde bulunulan gelişimsel döneme göre, koşullara göre ve kişiden kişiye değişebilir (Özkan, 2018).

Uyku sorunları, uyku alışkanlıklarının çocukları ve ailelerini zorladığı durumlar olarak tanımlanmaktadır. Uyku ve uyku düzensizlikleri, bebeklik döneminde çocukları olan ailelerin ve çocuk hekimlerinin sık karşılaştıkları sorunlardan biridir (Ceylan, Kahraman, \& Ülker, 2016; Gözün Kahraman \& Ceylan, 2018; Özkan, 2018). Bebeklerin uyku düzenleri birbirinden çok farklı olabilir; genelde bebeklerin duygusal, fiziksel, psikolojik gelişmeleri ve ebeveynlerin tavırları ile değişebilir (Lélis, Cipriano, Cardoso, Lima, \& Araújo, 2014; Martins et al., 2018).

Yapılan çalışmalarda bebeklerin uyku düzensizlikleriyle ilgili ailelerin sıklıkla geleneksel yöntemlere başvurdukları görülmektedir (Chung \& An, 2014; Güler, Avc1, Yiğit, \& Ortabağ, 2018; Lélis vd., 2014; Richardson, 2013). İnsanların sağlıkla ilgili inanç ve uygulamaları, içinde yaşadığı toplumun kültürünün bir parçasıdır. Her konuda olduğu gibi sağlıkla ilgili konularda da kültürün etkisi görülmektedir. Geleneksel uygulamalardan en çok etkilenen grupta ise bebekler yer almaktadır. Bu geleneksel uygulamalardan biri de

Page | 299

www.iiste.org 
bebeği uyutma şekilleridir (Chung \& An, 2014; Güler, Avc1, Yiğit, \& Ortabağ, 2018; Lélis vd., 2014; Richardson, 2013).

Uyutmak, insanın belli bir yerde ve konumda belirli bir süre için uyumasını sağlamak ve bunun gerçekleşmesi için çeşitli yöntemlerin uygulanmasıdır. Bu çalışma, 0-2 yaş çocukların uyku alışkanlıklarını saptamak, annelerin çocuklarını uyutmak için başvurdukları yöntemleri ve çocukların uyku düzeninin annelerin yaşam kalitelerine olan etkisini belirlemek amacı ile yapılmıştır.

\section{Materyal ve Metot}

\subsection{Araştırmanın Amacı ve Tipi}

Araştırma Zonguldak IIl Merkezinde 0-2 yaş çocukların uyku alışkanlıklarını saptamak, annelerin çocuklarını uyutmak için başvurdukları yöntemleri ve çocukların uyku düzeninin annelerin yaşam kalitelerine olan etkisini belirlemek amacı ile analitik nitelikte yapılmıştır.

\subsection{Araştırmanın Hipotezi}

Hipotez 1 (H1): Anneler çocuklarına uyku alışkanlığı kazandırmak için geleneksel yöntemler kullanmaktadır. Hipotez 2 (H2): Uyku düzeni bozuk olan çocukların annelerinin yaşam kaliteleri düşmüştür.

\subsection{Araştırmanın Yapılacă̆ Yer ve Özellikleri}

Araştırmanın uygulaması Zonguldak İl merkezinde bulunan aile sağlığı merkezlerinde gerçekleştirilmiştir. Araştırma verileri Şubat 2015-Mayıs 2015 tarihleri arasında toplanmıştır. Zonguldak İl Merkezinde bağlı 11 adet Aile Sağlı̆̆ Merkezi bulunmaktadır. Araştırma, örneklem grubuna seçilen 2 Aile Sağlığı Merkezinde (Bahçelievler Aile Sağlı̆̆ı Merkezi, Soğuksu Aile Sağlığı Merkezi) yapılmıştır.

Araştırma kapsamında seçilen Aile Sağlığı Merkezleri birbirinden uzakta olup çalışma, bu merkezlere bağlı 0-2 yaş çocuğu olan annelerden araştırma ölçütlerine uyan, araştırma onam formunu dolduran anneler ile gerçekleştirilmiştir. Çalışma; kurum yöneticileri ile görüşülerek uygun, belirlenen zamanlarda gerçekleştirilmiştir.

\subsection{Araștırmanin Evreni ve Örneklemi}

Araştırmanın evrenini Zonguldak İl merkezinde 11 aile sağlığ merkezinde bulunan 0-2 yaş çocuğu olan anneler oluşturmaktadır. Araştırma verileri Şubat 2015-Mayıs 2015 tarihleri arasında toplanmıştır.

Örneklem grubunu oluşturan 0-2 yaş çocuğu olan anne sayısına ulaşmak için basit rastgele yöntem ile 2 aile sağlığı merkezi araştırma kapsamına alınmıştır. Buna göre Bahçelievler Aile Sağlığı Merkezi ve Soğuksu Aile Sağ lığı Merkezi örneklem grubuna seçilen merkezler olmuştur.

Araştırma grubunu belirlenen aile sağlığı merkezlerine araştırmanın yapıldı̆̆ı tarihlerde herhangi bir nedenle başvuran, 0-2 yaş çocuğu olan ve araştırmaya katılmayı kabul eden 200 anne oluşturmuştur.

Annelere, 0-2 yaş çocukların uyku alışkanlıklarını saptamak, annelerin çocuklarını uyutmak için başvurdukları yöntemleri belirlemek için anket formu ve yaşam kalitelerini değerlendirmek için SF 36 Yaşam Kalitesi Ölçeği uygulanmıştır.

\section{Annelerin Araştırma Kapsamına Alınma Kriterleri}

- $0-2$ yaş aralığında çocuğu olan anne olmasi

- Araştırmaya katılmaya gönüllü ve yazılı onam formunu imzalamış olması

- Çocuğun herhangi bir kronik hastalığının olmaması

\subsection{Veri Toplama Araçları}

Verilerin toplanmasinda;

Anket Formu; literatür ve uzman görüşleri doğrultusunda annelere, 0-2 yaş çocukların uyku alışkanlıklarını saptamak, annelerin çocuklarını uyutmak için başvurdukları yöntemleri belirlemek amacı hazırlanmıştır. Yaşam Kalitesi Ölçeği (SF36); annelerin çocukların uyku düzeninden ne ölçüde etkilendiğini değerlendirmek amacı ile "yaşam kalitesi ölçeği” kullanılacaktır. Yaşam kalitesi ölçeği (SF 36), yaşam kalitesini ölçmede

Page | 300

www.iiste.org 
kullanılan en yaygın ölçeklerden biridir. Ware ve arkadaşları tarafindan 1992 yılında geliştirilmiş, Türkçe geçerlik ve güvenirlik çalışması Koçyiğit ve arkadaşları tarafindan yapılmıştır. Ölçekte, 36 madde ile sağlığın 8 alt boyutu (fiziksel işlev, fiziksel rol, yaşamsallık, mental rol, sosyal fonksiyon, mental sağlık, ağrı ve genel sağlık algısı gibi) incelenmektedir. SF36 Yaşam Kalitesi Ölçeği alt bileşenleri Şekil 1.'de gösterilmiştir. Değerlendirmede, her alt ölçek için ayrı ayrı puanlar elde edilmektedir. Ölçeğin ikinci sorusu son 12 ayda sağlıktaki değişim algısını içermekte, diğer sorular son dört hafta göz önüne alınarak değerlendirilmektedir. Ölçeğin dördüncü ve beşinci sorusu evet/hayır, diğer sorular likert tipi (3, 5 ve 6'lı) derecelendirme ile değerlendirilmektedir. Ölçeğin $1,6,7,8,9 \mathrm{a}, 9 \mathrm{~d}, 9 \mathrm{e}, 9 \mathrm{~h}, 11 \mathrm{~b}, 11 \mathrm{~d}$ maddeleri ters çevrilerek puanı hesaplanmaktadır. SF-36 sağlık durumunun olumsuz olduğu kadar olumlu yönlerini de değerlendirmektedir. Alt ölçeklerin puanları 0 ile 100 arasında değişmektedir ve yüksek puan iyi sağlık durumunu göstermektedir. Orijinal ölçeğin alt ölçeklerinin iç tutarlılık güvenirlik katsayısı (Cronbach alfa) 0.62-0.94 arasında, Türkçe geçerlilik ve güvenirlik çalışmasında alt ölçeklerinin Cronbach alfa değerleri 0.73-0.76 arasında bulunmuştur. Bizim yaptığımız çalışmada Cronbach alfa değerleri 0.74- 0.75 arasında bulunmuştur.

\subsection{Araştırmanin Uygulanması}

Çalışma, araştırmacılar tarafından 09.02.2015-31.05.2015 tarihleri arasında yapılmıştır. Veriler, aile sağlığ merkezlerinin uygun olduğu tarihlerde araştırmacılar tarafından, yüz yüze görüşme tekniği ile toplanmıştır.

\subsection{Araştırmanın Etik Boyutu}

Araştırmanın yürütülebilmesi için etik kurul izini $(06.02 .2015 / 24)$ ve kurumlardan izin alınmıştır.

\subsection{Verilerin Değerlendirilmesi}

İstatistiksel değerlendirmede SPSS 16.0 paket programı kullanılmıştır. Sayısal değişkenlerin normal dağılıma uygunlukları Shapiro-Wilk testi ile incelenmiştir. Tanımlayıcı istatistiklerde, sayısal veriler için ortalama \pm standart sapma (minimum-maksimum) değerleri; kategorik yapıdaki veriler sayı ve yüzde olarak ifade edilmiştir. Sayısal değişkenler bakımından parametrik test varsayımları sağlanamadığından iki grubun karşılaştırılmasında Mann-Whitney U ve Kruskall Wallis testi kullanılmıştır. Sonuçlar \%95 güven aralığında değerlendirilmiş ve $\mathrm{p}<0.05$ değeri anlamlı kabul edilmiştir.

\section{Bulgular ve Tartışma}

Araştırmaya katılan annelerin çocuklarının tanımlayıcı özellikleri incelendiğinde; \%25'inin 2-6 aylık, \%58'inin doğum şeklinin normal doğum olduğu, \%36.5'inin 3-6 kilo arasında, \%32'sinin 51-60 cm boyunda olduğu, \%96.5'inin sağlık problemi olmadığı, \%89.5'inin geçirmiş olduğu hastalık olmadığı, \%51.5'inin birinci çocuk olduğu ve \%36.5'inin bakıcısının olduğu saptanmıştır (Tablo 1).

Page | 301 
Tablo 1. Çocukların Tanımlayıcı Özellikleri

\begin{tabular}{|c|c|c|}
\hline Özellikler & Sayı $(n=200)$ & $\%$ \\
\hline \multicolumn{3}{|l|}{ Yaş } \\
\hline Yenidoğan (0-1 ay) & 34 & 17.0 \\
\hline 2-6 aylık & 50 & 25.0 \\
\hline 7-12 aylık & 46 & 23.0 \\
\hline 13-18 aylık & 29 & 14.5 \\
\hline 19-24 aylık & 41 & 20.5 \\
\hline \multicolumn{3}{|l|}{ Doğum Şekli } \\
\hline Normal Doğum & 116 & 58.0 \\
\hline Sezeryan & 84 & 42.0 \\
\hline \multicolumn{3}{|l|}{ Doğum Kilosu } \\
\hline $2500 \mathrm{~kg}$ ve alt 1 & 17 & 8.5 \\
\hline $2500-3000 \mathrm{~kg}$ & 77 & 38.5 \\
\hline $3000-3500 \mathrm{~kg}$ & 71 & 35.5 \\
\hline $3500-4000 \mathrm{~kg}$ & 29 & 14.5 \\
\hline Diğer & 6 & 3.0 \\
\hline \multicolumn{3}{|c|}{ Doğum Komplikasyonu } \\
\hline Evet & 14 & 7.0 \\
\hline Hayır & 186 & 93.0 \\
\hline \multicolumn{3}{|l|}{ Kilo } \\
\hline 3-6 kilo & 73 & 36.5 \\
\hline 7-10 kilo & 62 & 31.0 \\
\hline 11-14 kilo & 56 & 28.0 \\
\hline 15-18 kilo & 9 & 4.5 \\
\hline \multicolumn{3}{|l|}{ Boy } \\
\hline $41-50 \mathrm{~cm}$ & 20 & 10.0 \\
\hline $51-60 \mathrm{~cm}$ & 64 & 32.0 \\
\hline $61-70 \mathrm{~cm}$ & 38 & 19.0 \\
\hline $71-80 \mathrm{~cm}$ & 40 & 20.0 \\
\hline $81-90 \mathrm{~cm}$ & 31 & 15.5 \\
\hline $91-100 \mathrm{~cm}$ & 7 & 3.5 \\
\hline \multicolumn{3}{|c|}{ Sağlık Problemi Varlığı } \\
\hline Evet & 7 & 3.5 \\
\hline Hayır & 193 & 96.5 \\
\hline \multicolumn{3}{|c|}{ Geçirmiş Olduğu Hastalık } \\
\hline Evet & 21 & 10.5 \\
\hline Hayır & 179 & 89.5 \\
\hline \multicolumn{3}{|c|}{ Kaçıncı Çocuk Olduğu } \\
\hline Birinci & 103 & 51.5 \\
\hline İkinci & 63 & 31.5 \\
\hline Üçüncü & 27 & 13.5 \\
\hline Diğer & 7 & 3.5 \\
\hline \multicolumn{3}{|c|}{ Çocuğa Bakan Diğer Kişilerin Varlığı } \\
\hline Evet & 73 & 36.5 \\
\hline Hayır & 127 & 63.5 \\
\hline Toplam & 200 & 100.0 \\
\hline
\end{tabular}


Araştırmaya katılan ailelerin sosyodemografik özellikleri incelendiğinde, annelerin \%35'inin 18-25 yaş arasında, babaların 56.5'inin 22-32 yaş arasında olduğu, annelerin \%32.5' inin, babaların ise \%40.5' inin lise mezunu olduğu, annelerin \%29.5'inin babaların ise \%92'sinin çalıştı̆̆ saptanmıştır. Araştırmaya katılan ailelerin $\% 59.5$ 'inin gelirinin giderine eşit olduğu ve $\% 91$ 'inin çekirdek aile olduğu belirlenmiştir (Tablo 2).

Tablo 2. Ailenin Sosyodemografik Özellikleri

\begin{tabular}{|c|c|c|}
\hline$x^{2}$ & Sayı $(n=200)$ & $\%$ \\
\hline \multicolumn{3}{|l|}{ Anne yaşı } \\
\hline $18-25$ yaş & 70 & 35.0 \\
\hline $26-33$ yaş & 68 & 34.0 \\
\hline $34-41$ yaş & 53 & 26.5 \\
\hline $42-50$ yaş & 9 & 4.5 \\
\hline \multicolumn{3}{|l|}{ Baba yaşı } \\
\hline $22-32$ yaş & 113 & 56.5 \\
\hline $33-42$ yaş & 66 & 33.0 \\
\hline 43-53 yaş & 21 & 10.5 \\
\hline \multicolumn{3}{|l|}{ Anne eğitim durumu } \\
\hline Okuma yazma bilmiyor & 5 & 2.5 \\
\hline İlkokul mezunu & 50 & 25.0 \\
\hline Ortaokul mezunu & 37 & 18.5 \\
\hline Lise mezunu & 65 & 32.5 \\
\hline Üniversite ve üstü & 43 & 21.5 \\
\hline \multicolumn{3}{|l|}{ Baba eğitim durumu } \\
\hline Okuma yazma bilmiyor & 4 & 2.0 \\
\hline İlkokul mezunu & 22 & 11.0 \\
\hline Ortaokul mezunu & 37 & 18.5 \\
\hline Lise mezunu & 81 & 40.5 \\
\hline Üniversite ve üstü & 56 & 28.0 \\
\hline \multicolumn{3}{|l|}{ Annenin Çalışma Durumu } \\
\hline Çalışmıyor & 141 & 70.5 \\
\hline Çalışıyor & 59 & 29.5 \\
\hline \multicolumn{3}{|l|}{ Baba Çalışma Durumu } \\
\hline Çalışmiyor & 16 & 8.0 \\
\hline Çalışıyor & 184 & 92.0 \\
\hline \multicolumn{3}{|l|}{ Gelir durumu } \\
\hline Gelirim giderimden az & 44 & 22.0 \\
\hline Gelirim giderime eşit & 119 & 59.5 \\
\hline Gelirim giderimden fazla & 37 & 18.5 \\
\hline \multicolumn{3}{|l|}{ Aile tipi } \\
\hline Çekirdek aile (anne, baba ve çocuklar) & 182 & 91.0 \\
\hline Geniş aile (anne, baba, çocuklar, dede, babaanne vs.) & 18 & 9.0 \\
\hline Toplam & 200 & 100.0 \\
\hline
\end{tabular}

Araştırmaya katılan annelerin çocuklarının uyku alışkanlıkları incelendiğinde; çocukların $\% 25.5$ 'inin günde 2 kez uyuduğu, \%26.5'inin 12 saat ve yine \%26.5'inin 14 saat uyuduğu, \%38'inin uyurken emzik kullandığ $1, \% 21$ 'inin uyurken yanında nesne bulundurduğu, $\% 48.5$ 'inin yan yatar pozisyonda rahat uyuduğu ve \%82.5'inin annesi ile aynı odada uyuduğu saptanmıştır (Tablo 3). 
Tablo 3. Çocukların Uyku Alışkanlıkları

\begin{tabular}{|c|c|c|}
\hline Özellikler & Sayı $(n=200)$ & $\%$ \\
\hline \multicolumn{3}{|l|}{ Günde kaç kez uyuduğu } \\
\hline $1 \mathrm{kez}$ & 26 & 13.0 \\
\hline $2 \mathrm{kez}$ & 51 & 25.5 \\
\hline $3 \mathrm{kez}$ & 49 & 24.5 \\
\hline $4 \mathrm{kez}$ & 46 & 23.0 \\
\hline Diğer & 28 & 14.0 \\
\hline \multicolumn{3}{|l|}{ Günlük Ortalama Uyku Süresi } \\
\hline 8 saat & 16 & 8.0 \\
\hline 9 saat & 7 & 3.5 \\
\hline 10 saat & 31 & 15.5 \\
\hline 11 saat & 19 & 9.5 \\
\hline 12 saat & 53 & 26.5 \\
\hline 14 saat & 53 & 26.5 \\
\hline Diğer & 21 & 10.5 \\
\hline \multicolumn{3}{|l|}{ Emzik Kullanma Durumu } \\
\hline Evet & 76 & 38.0 \\
\hline Hayır & 38 & 62.0 \\
\hline \multicolumn{3}{|l|}{ Parmak Emme Durumu } \\
\hline Evet & 10 & 5.0 \\
\hline Hayır & 190 & 95.0 \\
\hline \multicolumn{3}{|c|}{ Uyurken yanında nesne/eşya bulundurma durumu } \\
\hline Evet & 42 & 21.0 \\
\hline Hayır & 158 & 79.0 \\
\hline \multicolumn{3}{|l|}{ Rahat Uyuma Pozisyonu } \\
\hline Sirt üstü & 77 & 38.5 \\
\hline Yan yatarak & 97 & 48.5 \\
\hline Yüz üstü & 26 & 13.0 \\
\hline \multicolumn{3}{|l|}{ Hangi odada uyuduğu } \\
\hline Benimle aynı odada & 165 & 82.5 \\
\hline Kendi odasinda & 19 & 9.5 \\
\hline Kardeşleri ile birlikte odalarında & 16 & 8.0 \\
\hline Toplam & 200 & 100.0 \\
\hline
\end{tabular}

Araştırmaya katılan annelerin çocuklarının beslenme alışkanlıkları incelendiğinde; çocukların \%43.5'inin şu anda anne sütü ile beslendiği ve \%21'inin uyumadan önce 1 biberon mama aldığ saptanmıştır (Tablo 4).

Araştırmaya katılan ebeveynlerin, çocukların uyku alışkanlıkları hakkındaki düşünceleri incelendiğinde; çocukların \%37'sinin gece uykusunun düzensiz olduğu, \%20'sinin gece uykusunun birinci aydan itibaren düzene girdiği, ebeveynlerin \%33.5'inin çocuğunu ayakta sallayarak uyuttuğu ve ebeveynlerin \%46's1 çocuğun uyku düzeninin yaşam kalitesini olumsuz etkilediğini ifade ettiği belirlenmiştir (Tablo 5). 
Tablo 4. Çocukların Beslenme Alışkanlıkları

\begin{tabular}{lcc}
\hline Özellikler & Sayı (n=200) & \% \\
\hline Şimdiki beslenme şekli & & 43.5 \\
Anne sütü & 87 & 13.0 \\
Biberon & 26 & 24.0 \\
Kaşı & 48 & 19.5 \\
Hepsi & 39 & 42.0 \\
\hline Uyumadan Önce Beslenme Durumu & & 8.5 \\
Emzirerek & 84 & 21.0 \\
1 biberon süt & 17 & 8.0 \\
1 biberon mama & 42 & 9.0 \\
1 kase çorba & 16 & 1.0 \\
1 kase yoğurt & 18 & 10.5 \\
1 kase meyve püresi & 2 & 100.0 \\
1 kase mama & 21 & 200 \\
\hline Toplam & & \\
\hline
\end{tabular}

Tablo 5. Ebeveynlerin Çocuklarının Uyku Alıșkanlıkları İle İlgili Düşünceleri

\begin{tabular}{lcc}
\hline Özellikler & Sayı (n=200) & \% \\
\hline Gece uykusu düzeni & 126 & 63.0 \\
Düzenli & 74 & 37.0 \\
Düzensiz & & \\
\hline Gece uykusunun ne zaman düzene girdiği & 74 & 37.0 \\
Düzensiz & 40 & 20.0 \\
Birinci aydan itibaren & 36 & 18.0 \\
İkinci aydan itibaren & 23 & 11.5 \\
Üçüncü aydan itibaren & 27 & 13.5 \\
Diğer & & \\
\hline Huzursuz olduğunda uyutma şeklinin değişme durumu & 115 & 57.5 \\
Evet değişiyor & 85 & 42.5 \\
Hayır değişmiyor & & \\
\hline Uyumadan önce bezini kontrol etme durumu & 185 & 92.5 \\
Evet & 15 & 7.5 \\
Hayır & & \\
\hline Uykuda ayrı kıyafet giydirme durumu & 101 & 50.5 \\
Evet & 99 & 49.5 \\
Hayır & & \\
\hline Uyutma şekli & 59 & 29.5 \\
Emzirerek & 67 & 33.5 \\
Ayağınızda sallayarak & 12 & 6.0 \\
Kucakta ya da battaniye içinde sallayarak & 8 & 4.0 \\
Yatakta yanına uzanıp emzirerek & 33 & 16.5 \\
Çocuğu beşiğe koyup kendi başına bırakarak & 17 & 8.5 \\
Beşiğini sallayarak & 4 & 2.0 \\
Diğer & & \\
\hline Çocuğun Uyku Düzeninin Yaşam Kalitesine Etkisi İle İlgili Düşünceleri & 108 & 54.0 \\
Yaşam kalitemi etkilemiyor & 92 & 46.0 \\
Yaşam kalitemi olumsuz etkiliyor & 200 & 100.0 \\
\hline Toplam & & \\
\hline & & \\
\hline & & \\
& & \\
\hline
\end{tabular}


Annelerin, SF 36 Yaşam Kalitesi Ölçeği alt boyutlarından aldıkları puanların ortalamaları incelendiğinde; annelerin ağrı boyutu puan ortalaması en düşük $(25.33 \pm 2.05)$ bulunurken, bunu sosyal işlev boyutu

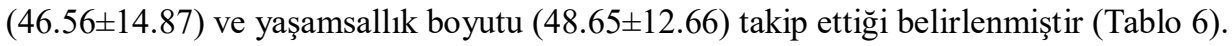

Tablo 6. Annelerin Yaşam Kalitesi Ölçeği Alt Boyutlarından Aldıkları Puan Ortalamalarının Dağılımı

\begin{tabular}{lccc}
\hline Yaşam Kalitesi Alt Boyutları & Ortalama \pm SS & $\begin{array}{c}\text { En Düşük } \\
\text { Puan }\end{array}$ & $\begin{array}{c}\text { En Yüksek } \\
\text { Puan }\end{array}$ \\
\hline Fiziksel işlev & $74.65 \pm 23.6$ & 0 & 100 \\
\hline Fiziksel rol & $63.62 \pm 43.8$ & 0 & 100 \\
\hline Ağrı & $\mathbf{2 5 . 3 3} \pm \mathbf{2 . 0 5}$ & 0 & 78 \\
\hline Genel sağlık algısı & $52.12 \pm 9.30$ & 20 & 75 \\
\hline Yaşamsallık & $\mathbf{4 8 . 6 5} \pm \mathbf{1 2 . 6 6}$ & 20 & 80 \\
\hline Sosyal işlev & $\mathbf{4 6 . 5 6} \pm \mathbf{1 4 . 8 7}$ & 0 & 88 \\
\hline Mental rol & $52.33 \pm 44.01$ & 0 & 100 \\
\hline Mental sağlık & $54.12 \pm 10.66$ & 8 & 76 \\
\hline
\end{tabular}

Türk toplumunun geleneksel yapısı nedeniyle çocukların bakımı çoğunlukla annededir. Çocuk bakımı ile ilgili yapılan çalışmalara bakıldığında bu çalışmaların çoğunlukla anneler ile yapıldığı görülmektedir (Ceylan et al., 2016; Erdoğan \& Turan, 2018; Gözün Kahraman \& Ceylan, 2018; Güler vd., 2018). Bu çalışmada annelerin yaş gruplarına göre, yaşam kalitesi alt boyutlarından aldıkları puanlar karşılaştırıldığında, yaşa göre fiziksel işlev $(\mathrm{p}=0.036)$ ve mental sağlık $(\mathrm{p}=0.027)$ alt boyutlarından aldıkları puanlar arasında istatistiksel olarak anlamlı farklılık saptanmıştır (Tablo 7). İleri yaş nedeniyle fiziksel olarak çocuğunun uyku problemleriyle baş edemeyen ailelerin yorgunluk hali nedeniyle sürekli mutsuz oldukları ve konforlarının düşük olduğu düşünülmektedir.

Martins ve ark. (2018) yenidoğan bebeği olan anneler ile yaptıkları deney-kontrol çalışmasında; anne eğitim düzeyinin yenidoğanların uyku alışkanlıkları üzerinde önemli olan birkaç faktörden biri olduğu bildirilmektedir. Aynı çalışmada uykuya yönelik eğitim alan annelerin bebeklerinde kendiliğinden kendi yataklarında uykuya dalma, uykuya dalmak için daha az emme ve biberon ile beslenme gereksinimi, gece kendiliğinden tekrar uykuya dalma görüldüğü bildirilmektedir. $\mathrm{Bu}$ çalışmada annelerin eğitim durumuna göre, yaşam kalitesi alt boyutlarından aldıkları puanlar karşılaştırıldığında, eğitim durumuna göre genel sağlık algısı $(\mathrm{p}=0.017)$ ve mental sağlı $(\mathrm{p}=0.050)$ alt boyutlarından aldıkları puanlar arasında istatistiksel olarak anlamlı farklılık saptanmıştır (Tablo 7). Bu annelerin bebeklerinin yukarıda belirtilen konular nedeniyle uyku sorunlarının olabileceği ve buna bağlı olarak annelerin gece uykusu kalitesinin ve yaşam kalitesinin düşük olduğu düşünülmektedir.

Uzun çalışma saatleri olan annelerin çocuklarının daha geç saatte uyuduğu ve çocuklarda 9,5 saatten daha az uyku olasılığını arttırdığı belirtilmektedir (Magee, Caputi, \& Iverson, 2012). Geç saatte uyuyan çocuklarda daha fazla gece uyanmalarının olduğu ve annelerinde yüksek düzeyde anksiyete görüldüğü bildirilmektedir (Cohenca-Shiby \& Schonbach-Medina, 2013). Bu çalışmada Annelerin çalışma durumuna göre, yaşam kalitesi alt boyutlarından aldıkları puanlar karşılaştırıldığında, istatistiksel olarak aralarında anlamlı farklılık saptanmamıştır ( $p>0.05$ ) (Tablo 7). Bu bulgu bize özellikle doğum sonrasında 0-24 ay dönemini kapsayan emzirmenin devamının sağlanması amaçlı çalışan annenlere yönelik kısmi süreli çalışma uygulamalarının etkin bir şekilde uygulandığını düşündürtmektedir. Doğum sonrası anneler için gerek doğum sonrası ücretli ve ücretisiz izinler ve gerekse de kısmı çalışma uygulamaları mevcuttur (T.C. Çalışma ve Sosyal Güvenlik Bakanlığı, 2016; Tuaç, 2017). Bu uygulamalar doğrultusunda çalışan annelerin bebek bakımı ile ilgili sıkıntı yaşamadıkları ve yaşam kalitelerinde düşme olmadığı düşünülmektedir.

Bebekler ilk günlerinde günün önemli bir bölümünü uykuda geçirirler. Özellikle yenidoğanlar 1-2 saatlik dönemler halinde günde ortalama 16-18 saat uyurlar. Gece ve gündüzü karıştırırlar; bazen gündüzü uyuyarak geçirirler. Ancak özellikle yenidoğan döneminde bebeklerin birçok konuda olduğu uyku için de anneye ihtiyaç duyması bu süreci zorlaştırabilmektedir (Özkan, 2018). Örneğin bu çalışmadaki Çocukların yaş

Page | 306

www.iiste.org 
gruplarına göre, annelerin yaşam kalitesi alt boyutlarından aldıkları puanlar karşılaştırıldığında, yaşa göre fiziksel işlev $(\mathrm{p}=0.037)$, fiziksel rol $(\mathrm{p}=0.000)$, ağr1 $(\mathrm{p}=0.000)$ ve mental rol $(\mathrm{p}=0.001)$ alt boyutlarından aldıkları puanlar arasında istatistiksel olarak anlamlı farklılık saptanmıştır (Tablo 8) Çalışmadaki yenidoğan bebeği olan annelerin bu nedenlerden dolayı dinlenememe ve fiziksel sağlık sorunları ile baş etmeye bağlı yaşanan duygusal problemler yaşadıkları düşünülmektedir. Ancak Cohenca-Shiby ve Schonbach-Medina (2013) çocuğun yaşının artmasıyla yatağa gitme süresinin uzadığı, gece uyanmalarının daha fazla olduğu belirtilmekte ve bu çocukların annelerinde yüksek anksiyete düzeyinin görüldüğüne dikkat çekmektedir. Benzer şekilde çocuğun gece uykusu düzenine göre, annelerin yaşam kalitesi alt boyutlarından aldıkları puanlar karşılaştırıldığında, gece uykusu düzenine göre fiziksel işlev ( $\mathrm{p}=0.000)$, fiziksel rol $(\mathrm{p}=0.000)$, ağrı $(\mathrm{p}=0.001)$, genel sağlık algısı $(\mathrm{p}=0.046)$ ve mental sağlık $(\mathrm{p}=0.018)$ alt boyutlarından aldıkları puanlar arasında istatistiksel olarak anlamlı farklılık saptanmıştır (Tablo 9).

Çocuklarda sağlık problemi varlı̆̆ına annelerin bakım yükünü arttırmaktadır. Çocuk bakımı zor ve uğraştıran bir süreçtir. Bu sürece sağlık problemi de eklenince bakım daha da zorlaşmaktadır. Özellikle hastalık durumlarında etkilenen temel gereksinimlerden biri uykudur. Çocuğun bakımını üstlenen anneler hastalık sürecinde çocuk ile beraber uykusuz kalabilmekte ve yorgunluk yaşayabilmektedir (Kostak, Kocaaslan, Bilsel, \& Mutlu, 2016; Martín Martín, Sánchez Bayle, \& Francisco, 2017; Waring, Kirk, \& Fallon, 2019). Waring ve ark.(2019) yaptıkları derlemede kronik öksürüğü olan çocuklar da ve ailelerinde uyku ve yaşam kalitesinin düştüğü, emosyonel distresin sık görüldüğü, günlük faaliyetlere katılımın azaldığ 1 ve sağlık profesyonellerine başvurunun arttığı bildirmektedir. Benzer şekilde bu çalışmada çocuklarda sağlı problemi varlığına göre, annelerin yaşam kalitesi alt boyutlarından aldıkları puanlar karşılaştırıldığında, sağlık problemi varlığına göre fiziksel rol $(\mathrm{p}=0.049)$ alt boyutundan aldıkları puanlar arasında istatistiksel olarak anlamlı farklılık saptanmıştır (Tablo 8).

0-2 yaş dönemi çocuk gereksinimleri doğrultusunda tümüyle bakım vericisine bağlıdır ve bu dönemde temel gereksinimlerin karşılanması önemlidir (Syed \& Mclean, 2017). Toplumumuzun yapısı gereği bakım görevinin annede olması bakım yükünün tek kişide yüklenmesine neden olmaktadır. Bununla beraber çocuk sayısının artması annelerin bakım yükünün de artmasına neden olmaktadır. Çalışmada çocuğun kaçıncı çocuk olduğuna göre, annelerin yaşam kalitesi alt boyutlarından aldıkları puanlar karşılaştırıldığında, kaçıncı çocuk olduğuna göre sosyal işlev ( $\mathrm{p}=0.050$ ) alt boyutundan aldıkları puanlar arasında istatistiksel olarak anlamlı farklılık saptanmıştır (Tablo 8). Çocuk sayısının artması annelerin bakım yükünü arttırmakta ve sosyalleşmelerini engellemektedir.

Çalışmada çocuğa bakan kişinin varlığına göre, annelerin yaşam kalitesi alt boyutlarından aldıkları puanlar karşılaştırıldığında, istatistiksel olarak aralarında anlamlı farklılık saptanmamıştır ( $\mathrm{p}>0.05)$ (Tablo 8). Oysaki evde anneye yardımcı birinin olmasının bakım yükünü azaltması ve dolasıyla anne yaşam kalitesini arttırması beklenmektedir. Ancak çocuğun bakım görevinin annede bulunduğuna dair algı nedeniyle her koşula çocukların bakımının annede olduğu buna bağlı olarak yaşam kalitesinde farklılık tespit edilmediği düşünülmektedir.

Page | 307

www.iiste.org 
International Journal of Scientific and Technological Research

ISSN 2422-8702 (Online), DOI: 10.7176/JSTR/5-2-36

Vol 5, No.2, 2019

\section{www.iiste.org}

ilish

Tablo 7. Annelerin Sosyodemografik Özelliklerine Göre Yaşam Kalitesi Ölçeği Alt Boyutlarının Puan Ortalamalarının Karşılaştırılması Yaşam Kalitesi Ölçeği Alt Boyutları

\begin{tabular}{|c|c|c|c|c|c|c|c|c|}
\hline $\begin{array}{l}\text { Sosyodemografik } \\
\text { Özellikler }\end{array}$ & $\begin{array}{c}\text { Fiziksel İşlev } \\
\text { Ort } \pm \text { SS(min-max) }\end{array}$ & $\begin{array}{c}\text { Fiziksel Rol } \\
\text { Ort } \pm \text { SS(min-max) }\end{array}$ & $\begin{array}{c}\text { Ağrı } \\
\text { Ort } \pm \text { SS(min-max) }\end{array}$ & $\begin{array}{c}\text { Genel Sağlık } \\
\text { Algısı } \\
\text { Ort } \pm \text { SS(min-max) } \\
\end{array}$ & $\begin{array}{c}\text { Yaşamsallık } \\
\text { Ort } \pm \text { SS(min-max) }\end{array}$ & $\begin{array}{c}\text { Sosyal İşlev } \\
\text { Ort } \pm \text { SS(min-max) }\end{array}$ & $\begin{array}{c}\text { Mental Rol } \\
\text { Ort } \pm \text { SS(min-max) }\end{array}$ & $\begin{array}{c}\text { Mental Sağlık } \\
\text { Ort } \pm \text { SS(min-max) }\end{array}$ \\
\hline \multicolumn{9}{|l|}{ Anne yaşı } \\
\hline $18-25$ yaş & $78.85 \pm 24.5(10-100)$ & $61.42 \pm 43.7(0-100)$ & $25.39 \pm 2.03(0-78)$ & $53.42 \pm 9.42(20-75)$ & $47.64 \pm 12.6(20-70)$ & $47.32 \pm 14.7(0-75$ & $46.19 \pm 44.4(0-100)$ & $53.42 \pm 10.6(16-72)$ \\
\hline $26-33$ yaş & $74.77 \pm 24.5(5-100)$ & $69.48 \pm 42.0(0-100)$ & $24.83 \pm 2.30(0-78)$ & $52.57 \pm 8.65(35-70)$ & $48.67 \pm 13.1(20-80)$ & $49.44 \pm 14.0(25-88)$ & $57.84 \pm 43.7(0-100)$ & $56.17 \pm 10.5(16-76)$ \\
\hline $34-41$ yaş & $69.52 \pm 21.1(0-100)$ & $57.07 \pm 47.1(0-100)$ & $26.62 \pm 1.84(0-67)$ & $50.56 \pm 9.73(30-65)$ & $51.03 \pm 11.6(25-75)$ & $43.39 \pm 15.0(0-75)$ & $54.71 \pm 44.8(0-100)$ & $53.66 \pm 10.4(8-68)$ \\
\hline $42-50$ yaş & $71.11 \pm 18.1(45-90)$ & $75.0 \pm 35.3(0-100)$ & $20.98 \pm 1.51(0-45)$ & $47.77 \pm 9.39(30-60)$ & $42.22 \pm 13.9(25-60)$ & $37.50 \pm 16.5(0-50)$ & $44.44 \pm 37.2(0-100)$ & $46.66 \pm 9.79(32-60)$ \\
\hline \multicolumn{9}{|l|}{ Test ve p değeri } \\
\hline $\mathrm{KW}^{*} ; \mathrm{p}$ & $8.553 ; 0.036$ & $2.727 ; 0.436$ & $1.297 ; 0.730$ & $4.505 ; 0.212$ & $4.237 ; 0.237$ & $7.487 ; 0.058$ & $2.553 ; 0.466$ & $9.201 ; 0.027$ \\
\hline \multicolumn{9}{|l|}{ Anne eğitim durumu } \\
\hline Okuma yazma bilmiyor & $62.00 \pm 16.8(50-90)$ & $45.0 \pm 51.2(0-100)$ & $31.11 \pm 1.44(11-45)$ & $53.0 \pm 5.70(45-60)$ & $49.0 \pm 11.9(35-65)$ & $50.00 \pm 8.83(38-63)$ & $33.33 \pm 40.8(0-100)$ & $52.00 \pm 10.58(36-64)$ \\
\hline İlkokul mezunu & $76.90 \pm 19.8(20-100)$ & $63.0 \pm 43.2(0-100)$ & $24.66 \pm 1.78(0-67)$ & $49.80 \pm 10.6(30-70)$ & $45.30 \pm 11.4(25-70)$ & $43.25 \pm 14.9(0-75)$ & $52.00 \pm 42.6(0-100)$ & $51.92 \pm 10.6(24-72)$ \\
\hline Ortaokul mezunu & $76.62 \pm 25.9(0-100)$ & $69.59 \pm 40.0(0-100)$ & $21.12 \pm 1.81(0-67)$ & $55.94 \pm 8.06(35-75)$ & $48.24 \pm 13.4(25-70)$ & $47.29 \pm 13.2(0-75)$ & $54.05 \pm 40.3(0-100)$ & $56.32 \pm 10.3(16-72)$ \\
\hline Lise Mezunu & $69.76 \pm 25.3(10-100)$ & $60.00 \pm 45.0(0-100)$ & $25.81 \pm 2.07(0-78)$ & $50.76 \pm 9.02(20-70)$ & $51.30 \pm 13.0(20-75)$ & $47.69 \pm 15.4(0-88)$ & $52.82 \pm 47.1(0-100)$ & $55.13 \pm 12.0(8-76)$ \\
\hline \multirow{2}{*}{\multicolumn{9}{|c|}{ Test ve p değeri }} \\
\hline & & & & & & & & \\
\hline $\mathrm{KW}^{*} ; \mathrm{p}$ & $6.988 ; 0.137$ & $3.179 ; 0.528$ & $1.876 ; 0.759$ & $12.036 ; 0.017$ & $7.596 ; 0.108$ & $4.448 ; 0.349$ & $0.816 ; 0.936$ & $9.500 ; 0.050$ \\
\hline \multicolumn{9}{|l|}{ Annenin Calıșma Durumu } \\
\hline Çalışmıyor & $75.28 \pm 22.9(0-100)$ & $66.48 \pm 42.0(0-100)$ & $24.27 \pm 1.80(0-78)$ & $52.58 \pm 9.21(30-75)$ & $48.90 \pm 13.1(20-75)$ & $45.74 \pm 14.7(0-75)$ & $52.24 \pm 44.0(0-100)$ & $54.72 \pm 10.9(8-72)$ \\
\hline Çalışıor & $73.13 \pm 25.3(5-100)$ & $56.77 \pm 47.5(0-100)$ & $27.87 \pm 2.54(0-78)$ & $51.01 \pm 9.50(20-75)$ & $48.05 \pm 11.5(20-80)$ & $48.51 \pm 15.2(0-88)$ & $52.54 \pm 44.2(0-100)$ & $52.67 \pm 9.99(16-76)$ \\
\hline \multicolumn{9}{|l|}{ Test ve p değeri } \\
\hline $\mathrm{U}^{* *} ; \mathrm{p}$ & $-0.366 ; 0.714$ & $-1.156 ; 0.248$ & $-0.511 ; 0.610$ & $-1.399 ; 0.162$ & $-0.658 ; 0.510$ & $-1.370 ; 0.171$ & $-0.101 ; 0.920$ & $-1.866 ; 0.062$ \\
\hline \multicolumn{9}{|l|}{ Gelir durumu } \\
\hline Gelirim giderimden az & $70.56 \pm 25.0(0-100)$ & $55.11 \pm 44.6(0-100)$ & $28.03 \pm 1.90(0-78)$ & $51.59 \pm 9.98(30-70)$ & $47.15 \pm 12.3(25-70)$ & $42.89 \pm 13.0(0-63)$ & $40.90 \pm 44.2(0-100)$ & $51.81 \pm 11.9(24-72)$ \\
\hline Gelirim giderime eşit & $75.75 \pm 23.0(5-100)$ & $65.12 \pm 43.0(0-100)$ & $26.79 \pm 2.07(0-78)$ & $52.47 \pm 9.45(20-75)$ & $49.74 \pm 12.3(20-80)$ & $47.79 \pm 14.8(0-88)$ & $52.94 \pm 44.3(0-100)$ & $54.92 \pm 10.5(8-76)$ \\
\hline Gelirim giderimden fazla & $75.94 \pm 24.0(10-100)$ & $68.91 \pm 45.0(0-100)$ & $17.41 \pm 2.02(0-67)$ & $51.62 \pm 8.08(35-65)$ & $46.89 \pm 13.8(20-75)$ & $46.95 \pm 16.5(0-75)$ & $63.96 \pm 40.3(0-100)$ & $54.27 \pm 9.35(36-72)$ \\
\hline \multicolumn{9}{|l|}{ Test ve $p$ değeri } \\
\hline $\mathrm{KW}^{*} ; \mathrm{p}$ & $1.916 ; 0.384$ & $3.243 ; 0.198$ & $7.801 ; 0.020$ & $0.789 ; 0.674$ & $2.469 ; 0.291$ & $4.842 ; 0.089$ & $4.963 ; 0.084$ & $2.455 ; 0.293$ \\
\hline \multicolumn{9}{|l|}{ Aile tipi } \\
\hline Cekirdek aile & $74.56 \pm 24.0(0-100)$ & $63.87 \pm 43.6(0-100)$ & $25.70 \pm 2.06(0-78)$ & $52.14 \pm 9.33(20-75)$ & $48.51 \pm 12.7(20-80)$ & $46.35 \pm 14.6(0-75)$ & $50.73 \pm 44.1(0-100)$ & $54.17 \pm 10.8(8-76)$ \\
\hline Geniş aile & $75.55 \pm 20.4(45-100)$ & $61.11 \pm 47.1(0-100)$ & $21.60 \pm 1.99(0-67)$ & $51.94 \pm 9.25(30-65)$ & $50.00 \pm 12.3(20-65)$ & $48.61 \pm 17.6(0-88)$ & $68.51 \pm 40.3(0-100)$ & $53.55 \pm 8.36(36-68)$ \\
\hline \multicolumn{9}{|l|}{ Test ve $p$ değeri } \\
\hline $\mathrm{U}^{* *} ; \mathrm{p}$ & $-0.184 ; 0.854$ & $-0.127 ; 0.899$ & $-0.838 ; 0.402$ & $-0.074 ; 0.941$ & $-0.782 ; 0.434$ & $-0.594 ; 0.552$ & $-1.654 ; 0.098$ & $-0.647 ; 0.517$ \\
\hline
\end{tabular}

*Kruskall Wallis Testi

**Mann Whitney U Testi

Page | 308

www.iiste.org 
International Journal of Scientific and Technological Research

ISSN 2422-8702 (Online), DOI: 10.7176/JSTR/5-2-36

Vol 5, No.2, 2019

\section{www.iiste.org}

$\|$ isil

Tablo 8. Çocuklara Ait Özelliklerine Göre Yaşam Kalitesi Ölçeği Alt Boyutlarının Puan Ortalamalarının Karşılaştırılması Yaşam Kalitesi Ölçeği Alt Boyutları

\begin{tabular}{|c|c|c|c|c|c|c|c|c|}
\hline $\begin{array}{l}\text { Sosyodemografik } \\
\text { Özellikler }\end{array}$ & $\begin{array}{c}\text { Fiziksel İşlev } \\
\text { Ort } \pm \text { SS(min-max) }\end{array}$ & $\begin{array}{c}\text { Fiziksel Rol } \\
\text { Ort } \pm \text { SS(min-max) }\end{array}$ & $\begin{array}{c}\text { Ağrı } \\
\operatorname{Ort} \pm \text { SS(min-max) }\end{array}$ & $\begin{array}{c}\text { Genel Sağlık } \\
\text { Algısl } \\
\text { Ort } \pm \text { SS(min-max })\end{array}$ & $\begin{array}{c}\text { Yaşamsallık } \\
\text { Ort } \pm \text { SS(min-max) }\end{array}$ & $\begin{array}{c}\text { Sosyal İşlev } \\
\text { Ort } \pm \text { SS(min-max) }\end{array}$ & $\begin{array}{c}\text { Mental Rol } \\
\text { Ort } \pm \text { SS(min-max) }\end{array}$ & $\begin{array}{c}\text { Mental Sağlık } \\
\text { Ort } \pm \text { SS(min-max) }\end{array}$ \\
\hline \multicolumn{9}{|l|}{ Çocuğun Yaşı } \\
\hline Yenidoğan $(0-1$ ay) & $64.11 \pm 28.4(5-100)$ & $45.58 \pm 46.2(0-100)$ & $36.27 \pm 2.21(0-78)$ & $54.70 \pm 7.87(35-70$ & $48.52 \pm 14.2(25-80)$ & $50.00 \pm 9.73(38-75)$ & $49.01 \pm 39.5(0-100)$ & $55.76 \pm 13.2(8-72)$ \\
\hline $2-6$ aylik & $73.70 \pm 23.2(0-100)$ & $51.50 \pm 45.0(0-100)$ & $26.66 \pm 2.23(0-78)$ & $52.30 \pm 9.90(20-75)$ & $49.40 \pm 12.9(25-75)$ & $44.00 \pm 16.9(0-75)$ & $36.00 \pm 42.5(0-100)$ & $53.28 \pm 10.7(24-68)$ \\
\hline $7-12$ aylık & $74.34 \pm 23.9(10-100)$ & $64.13 \pm 43.3(0-100)$ & $29.46 \pm 2.03(0-78)$ & $51.19 \pm 8.44(30-60)$ & $49.02 \pm 11.3(25-70)$ & $49.18 \pm 15.2(0-75)$ & $47.10 \pm 45.8(0-100)$ & $55.04 \pm 10.3(16-76)$ \\
\hline 13-18 aylık & $77.41 \pm 21.3(45-100)$ & $71.55 \pm 40.4(0-100)$ & $16.09 \pm 1.58(0-45)$ & $52.06 \pm 10.7(30-75)$ & $46.20 \pm 13.1(20-70)$ & $43.53 \pm 12.7(0-63)$ & $72.41 \pm 38.9(0-100)$ & $51.31 \pm 10.6(16-64)$ \\
\hline 19-24 aylık & $82.92 \pm 18.1(45-100)$ & $87.19 \pm 31.1(0-100)$ & $16.53 \pm 1.34(0-45)$ & $50.85 \pm 9.48(30-70$ & $49.14 \pm 12.3(20-65)$ & $46.03 \pm 16.1(0-88)$ & $66.66 \pm 42.8(0-100)$ & $54.73 \pm 8.41(32-68)$ \\
\hline \multicolumn{9}{|l|}{ Test ve $\mathrm{p}$ değeri } \\
\hline $\mathrm{KW}^{*} ; \mathrm{p}$ & $10.189 ; 0.037$ & 27.173;0.000 & $23.603 ; 0.000$ & $3.910 ; 0.418$ & $1.357 ; 0.852$ & $4.863 ; 0.302$ & $18.052 ; 0.001$ & $4.794 ; 0.309$ \\
\hline \multicolumn{9}{|c|}{ Sağlık Problemi Varlığı } \\
\hline Evet & $60.71 \pm 15.9(50-90)$ & $28.57 \pm 48.7(0-100)$ & $20.63 \pm 1.34(0-45)$ & $56.42 \pm 7.48(45-65)$ & $56.42 \pm 13.1(35-75)$ & $48.21 \pm 15.1(25-75)$ & $61.90 \pm 44.8(0-100)$ & $53.71 \pm 11.9(36-68)$ \\
\hline Hayır & $75.15 \pm 23.7(0-100)$ & $64.89 \pm 43.2(0-100)$ & $25.50 \pm 2.07(0-78)$ & $51.96 \pm 9.34(20-75)$ & $48.36 \pm 12.5(20-80)$ & $46.50 \pm 14.9(0-88)$ & $51.98 \pm 44.0(0-100)$ & $54.13 \pm 10.6(8-76)$ \\
\hline \multicolumn{9}{|l|}{ Test ve $p$ değeri } \\
\hline $\mathrm{U}^{* *} ; \mathrm{p}$ & $-1.874 ; 0.061$ & $-1.972 ; 0.049$ & $-0.528 ; 0.598$ & $-1.234 ; 0.217$ & $-1.580 ; 0.114$ & $-0.075 ; 0.940$ & $-0.455 ; 0.649$ & $-0.003 ; 0.997$ \\
\hline \multicolumn{9}{|l|}{ Kaçıncı Çocuk } \\
\hline Birinci & $76.31 \pm 23.8(5-100)$ & $63.10 \pm 43.7(0-100)$ & $25.89 \pm 2.08(0-78)$ & $52.76 \pm 9.69(20-75)$ & $48.10 \pm 12.9(20-80)$ & $47.45 \pm 12.9(0-75)$ & $48.54 \pm 44.9(0-100)$ & $54.17 \pm 10.5(16-76)$ \\
\hline İkinci & $75.87 \pm 22.2(10-100)$ & $62.30 \pm 44.1(0-100)$ & $25.74 \pm 2.15(0-78)$ & $51.82 \pm 7.99(35-70)$ & $49.92 \pm 12.5(20-75)$ & $49.20 \pm 15.0(0-88)$ & $52.91 \pm 43.4(0-100)$ & $54.41 \pm 11.8(8-72)$ \\
\hline Ücüncü & $67.77 \pm 26.7(0-100)$ & $67.59 \pm 44.8(0-100)$ & $20.98 \pm 1.90(0-45)$ & $50.74 \pm 9.57(30-65)$ & $48.51 \pm 12.1(25-65)$ & $37.03 \pm 19.4(0-63)$ & $61.72 \pm 42.0(0-100)$ & $54.37 \pm 8.75(32-64)$ \\
\hline \multirow{2}{*}{\multicolumn{9}{|c|}{$\begin{array}{l}\text { Diger } \\
\text { Test ve p değeri }\end{array}$}} \\
\hline & & & & & & & & \\
\hline $\mathrm{KW}^{*} ; \mathrm{p}$ & $3.920 ; 0.270$ & $0.626 ; 0.890$ & $1.657 ; 0.647$ & $1.357 ; 0.716$ & $1.217 ; 0.749$ & $7.830 ; 0.050$ & $3.075 ; 0.380$ & $2.677 ; 0.444$ \\
\hline $\begin{array}{lr}\text { Çocuğa } & \text { Bakan } \\
\text { Diŏer } & \text { Kisilerin }\end{array}$ & & & & & & & & \\
\hline Evet & $74.31 \pm 23.3(5-100)$ & $57.19 \pm 45.5(0-100)$ & $28.15 \pm 2.45(0-78)$ & $51.02 \pm 8.97(20-70)$ & $47.94 \pm 11.3(20-70)$ & $49.14 \pm 15.0(0-88)$ & $52.05 \pm 41.9(0-100)$ & $53.64 \pm 10.1(8-76)$ \\
\hline Hayır & $74.84 \pm 23.9(0-100)$ & $67.32 \pm 42.5(0-100)$ & $23.70 \pm 1.77(0-68)$ & $52.75 \pm 9.46(30-75)$ & $49.05 \pm 13.4(20-80)$ & $45.07 \pm 14.6(0-75)$ & $52.49 \pm 45.3(0-100)$ & $54.39 \pm 10.9(16-72)$ \\
\hline \multicolumn{9}{|l|}{ Test ve $p$ değeri } \\
\hline $\mathrm{U}^{* *} ; \mathrm{p}$ & $-0.200 ; 0.841$ & $-1.619 ; 0.105$ & $-0.827 ; 0.408$ & $-1.410 ; 0.159$ & $-0.626 ; 0.531$ & $-1.710 ; 0.087$ & $-0.100 ; 0.921$ & $-1.184 ; 0.236$ \\
\hline
\end{tabular}

Page | 309

www.iiste.org 
Çocuğun günlük ortalama uyku süresine göre, annelerin yaşam kalitesi alt boyutlarından aldıkları puanlar karşılaştırıldığında, günlük ortalama uyku süresine göre fiziksel işlev ( $\mathrm{p}=0.024)$, fiziksel rol $(\mathrm{p}=0.026)$, genel sağlık algısı $(\mathrm{p}=0.002)$ ve yaşamsallık $(\mathrm{p}=0.016)$ alt boyutlarından aldıkları puanlar arasında istatistiksel olarak anlamlı farklılık saptanmıştır (Tablo 9). Bu annelerin belirtilen alt boyutlarda yaşadıkları sıkıntılar nedeniyle de genel sağlık algılarının kötü olduğu düşünülmektedir. Benzer şekilde çalışmaya dahil edilen çocuklarının günde bir kez uyuduğunu bildiren annelerin daha fazla ağrı deneyimlediği belirlenmiştir. $\mathrm{Bu}$ bulgu doğrultusunda çocuğun uyuduğu zamanları annelerin de uyuyarak değerlendirdiği, gün içerisinde daha az uyuyan çocuğa sahip annelerin dinlenmek için firsat bulamadığı düşünülmektedir.

Çalışmada çocuğun günlük uyku sayısına göre, annelerin yaşam kalitesi alt boyutlarından aldıkları puanlar karşılaştırıldığında, günlük uyku sayısına göre ağrı $(\mathrm{p}=0.033)$ alt boyutundan aldıkları puanlar arasında istatistiksel olarak anlamlı farklılık saptanmıştır (Tablo 9). Yine bu durumla ilişkili olarak özellikle uykusu birinci aydan itibaren düzene giren çocukların sonraki yaş dönemlerinde düzenli gece uykusuna geçen çocukların annelerinde de benzer sonuçlar elde edilmiştir. Bu durum özellikle çalışmaya dahil edilen çocukların çoğunun anne sütü ile beslenmesi ve uyumadan önce beslenme gereksinimi ile ilişkilendirilmiştir. Ayrıca Kahraman ve Ceylan (2018)'ın 0-3 yaş gurubu çocuğu olan 325 anne ile yaptıkları çalışmada çocukların çoğunun ebeveyn katılımı ile uykuya daldıkları bildirilmektedir. Çınar ve ark.(2010) 0-12 aylık sağlıklı bebeğe sahip 254 anne ile yaptıkları çalışmada ise annelerin \%81,5'inin bebekleri ile aynı odada uyuduğu bildirilmektedir. Özellikle gece anne sütüne ya da biberon ile beslenme gereksinimi olan çocukların sıklıkla anne ile aynı odada uyuduğu yorumu yapılabilir.

Çocukların iyi uyuma alışkanlıklarıyla doğduğu ve bu alışkanlıkları sonrasında da öğrenebilecekleri inancı kuvvetlidir. Bu noktada özellikle annelerin çocuklarını uyutmak için kullandığı yöntemler önem arz etmektedir (Lélis vd., 2014; Martins vd., 2018; Mindell, Sadeh, Kohyama, \& How, 2010). Ahn ve ark.(2016) 1,036 yenidoğana bakım veren kişi ile yaptıkları çalışmada en sık gece uyanmalarının ve tekrar uykuya dalma için gerekli eylemin emme ya da biberon ile beslenme olduğunu bildirmektedir (Ahn, Williamson, Seo, Sadeh, \& Mindell, 2016). Bu çalışmadaki annenin çocuğu uyutma şekline göre, annelerin yaşam kalitesi alt boyutlarından aldıkları puanlar karşılaştırıldığında, çocuğu uyutma şekline göre mental rol $(p=0.007)$ alt boyutundan aldıkları puanlar arasında istatistiksel olarak anlamlı farklılık saptanmıştır (Tablo 9). Çocukların uyuması için emme işlevinin gereksinimi ya da gece uyanan çocukların emmek istemesi annelerin duygusal sorunlar nedeniyle günlük aktivitelerinde kesintiye uğradığı belirlenmiştir. Bu nedenle çocuğun gece emmek istemesinin annenin de uyanmasına ve uyku kalitesinin dolasıyla yaşam kalitesinin düştüğü düşünülmektedir. Ancak Figueiredo ve ark.(2017) 163 yenidoğanın anne ile yaptıkları çalışmada sadece anne sütü ile beslenen yenidoğanların kısmen anne sütü alan ve sadece mama ile beslenen yenidoğanlara göre daha sık uyandığ 1 bildirilmekte ancak anne depresyon ve anksiyetesi üzerinde etkisi olmadığı bildirilmektedir.

Annelerin çocuğun uyku düzeninin yaşam kalitelerine etkisi ile ilgili düşüncelerine göre, annelerin yaşam kalitesi ölçeği alt boyutlarından aldıkları puanlar karşılaştırıldığında, çocuğun uyku düzeninin yaşam kalitelerine etkisi ile ilgili düşüncelerine göre fiziksel işlev $(\mathrm{p}=0.000)$, fiziksel rol $(\mathrm{p}=0.000)$, ağrı $(\mathrm{p}=0.000)$, genel sağlık algısı $(\mathrm{p}=0.016)$ ve mental $\mathrm{rol}(\mathrm{p}=0.000)$ alt boyutlarından aldıkları puanlar arasında istatistiksel olarak anlamlı farklılık saptanmıştır (Tablo 9). Mindell ve ark.(2015) 10,085 anne ile yaptıkları çalışmada, annelerin çocuklarının uyku durumunun kendi uyku durumu ve günlük fonksiyonlarını etkilediğini ve çocuklarının uyku düzenini sağlamada yetersiz hissetmelerine neden olabileceğini ifade ettikleri bildirilmektedir (Mindell, Sadeh, Kwon, \& Goh, 2015). Benzer şekilde bu çalışmada çocuğunun uyku kalitesinin kendisinin yaşam kalitesini olumsuz etkilemediğini düşünen annelerin olumsuz etkilediğini düşünen annelere göre daha az fiziksel ve duygusal sorun yaşadığı, genel sağlık algılarının daha yüksek olduğu görülmektedir.

Page | 310

www.iiste.org 
International Journal of Scientific and Technological Research

ISSN 2422-8702 (Online), DOI: 10.7176/JSTR/5-2-36

Vol 5, No.2, 2019

\section{www.iiste.org}

IISTE

Tablo 9. Çocukların Uyku Alışkanlıklarına Ait Özelliklerine Göre Yaşam Kalitesi Ölçeği Alt Boyutlarının Puan Ortalamalarının Karşılaştırılması

Yaşam Kalitesi Ölçeği Alt Boyutları

\begin{tabular}{|c|c|c|c|c|c|c|c|c|}
\hline Sosyodemografik Özellikler & $\begin{array}{c}\text { Fiziksel İșlev } \\
\text { Ort } \pm \text { SS(min-max) }\end{array}$ & $\begin{array}{c}\begin{array}{c}\text { Fiziksel Rol Ort } \pm \text { SS(min- } \\
\text { max) }\end{array} \\
\end{array}$ & $\begin{array}{c}\text { Ağrı } \\
\text { Ort } \pm \text { SS(min-max) }\end{array}$ & $\begin{array}{l}\text { Genel Sağılk Algısı } \\
\text { Ort } \pm \text { SS(min-max) }\end{array}$ & $\begin{array}{c}\text { Yaşamsallık } \\
\text { Ort } \pm \text { SS(min-max) }\end{array}$ & $\begin{array}{c}\text { Sosyal İșlev } \\
\text { Ort } \pm \text { SS }(\text { min-max }) \\
\end{array}$ & $\begin{array}{c}\text { Mental Rol } \\
\text { Ort } \pm \text { SS(min-max) }\end{array}$ & $\begin{array}{c}\text { Mental Sağllk } \\
\text { Ort } \pm \text { SS(min-max) } \\
\end{array}$ \\
\hline \multicolumn{9}{|l|}{ Çocuğun Günlük Ortalama Uyku Süresi } \\
\hline 8 saat & $67.81 \pm 22.1(25-100)$ & $78.12 \pm 40.6(0-100)$ & $17.36 \pm 1.85(0-45)$ & $51.87 \pm 10.9(30-70)$ & $49.37 \pm 13.8(25-75)$ & $41.40 \pm 15.6(0-63)$ & $68.75 \pm 41.2(0-100)$ & $56.75 \pm 8.16(36-68)$ \\
\hline 9 saat & $75.71 \pm 13.0(50-90)$ & $39.28 \pm 49.7(0-100)$ & $23.80 \pm 2.96(0-78)$ & $56.42 \pm 8.99(45-70)$ & $46.42 \pm 14.3(25-70)$ & $37.50 \pm 17.6(0-50)$ & $38.09 \pm 44.8(0-100)$ & $55.42 \pm 8.46(44-68)$ \\
\hline 10 saat & $73.22 \pm 23.9(10-100)$ & $66.93 \pm 42.5(0-100)$ & $25.44 \pm 2.13(0-67)$ & $50.00 \pm 8.75(30-65)$ & $53.87 \pm 10.3(25-70)$ & $47.58 \pm 14.2(0-75)$ & $56.98 \pm 48.0(0-100)$ & $54.70 \pm 9.87(32-72)$ \\
\hline 11 saat & $61.05 \pm 23.3(10-100)$ & $43.42 \pm 47.0(0-100)$ & $35.67 \pm 2.08(0-78)$ & $55.00 \pm 7.45(45-75)$ & $54.47 \pm 10.2(30-65)$ & $46.05 \pm 17.2(0-75)$ & $31.57 \pm 43.7(0-100)$ & $53.47 \pm 7.91(40-64)$ \\
\hline 12 saat & $79.90 \pm 21.9(0-100)$ & $68.39 \pm 43.0(0-100)$ & $23.27 \pm 2.03(0-78)$ & $48.30 \pm 9.24(20-65)$ & $45.94 \pm 12.4(20-70)$ & $47.16 \pm 12.4(25-75)$ & $54.71 \pm 42.9(0-100)$ & $51.16 \pm 13.6(8-76)$ \\
\hline 14 saat & $79.81 \pm 20.6(45-100)$ & $71.22 \pm 39.3(0-100)$ & $22.85 \pm 1.66(0-67)$ & $54.05 \pm 9.04(30-75)$ & $47.54 \pm 12.3(20-70)$ & $46.69 \pm 17.0(0-88)$ & $50.94 \pm 44.1(0-100)$ & $54.79 \pm 9.62(28-72)$ \\
\hline Diğer & $67.61 \pm 32.1(5-100)$ & $42.85 \pm 46.1(0-100)$ & $33.86 \pm 2.34(0-78)$ & $56.19 \pm 7.73(40-65)$ & $45.47 \pm 14.8(25-80)$ & $50.59 \pm 11.5(25-75)$ & $53.96 \pm 40.1(0-100)$ & $57.14 \pm 9.56(44-72)$ \\
\hline \multicolumn{9}{|l|}{ Test ve $p$ değeri } \\
\hline$\underline{\mathrm{KW} ; \mathrm{p}}$ & $14.540 ; 0.024$ & $14.393 ; 0.026$ & $11.592 ; 0.072$ & 21.176;0.002 & $15.593 ; 0.016$ & $5.299 ; 0.506$ & $7.301 ; 0.294$ & $4.414 ; 0.621$ \\
\hline \multicolumn{9}{|l|}{ Çocuğun günde kaç kez uyuduğu } \\
\hline $1 \mathrm{kez}$ & $76.34 \pm 19.6(45-100)$ & $70.19 \pm 42.4(0-100)$ & $18.80 \pm 1.59(0-78)$ & $53.07 \pm 8.13(35-70)$ & $50.19 \pm 12.8(25-65)$ & $47.11 \pm 12.4(25-75)$ & $43.58 \pm 43.9(0-100)$ & $54.30 \pm 7.34(40-68)$ \\
\hline $2 \mathrm{kez}$ & $79.11 \pm 20.9(25-100)$ & $71.76 \pm 42.7(0-100)$ & $21.13 \pm 2.03(0-78)$ & $52.84 \pm 9.75(30-75)$ & $48.33 \pm 12.2(20-75)$ & $46.81 \pm 14.9(0-88)$ & $62.74 \pm 40.9(0-100)$ & $52.31 \pm 9.11(32-68)$ \\
\hline $3 \mathrm{kez}$ & $70.10 \pm 26.6(0-100)$ & $61.22 \pm 44.5(0-100)$ & $25.17 \pm 2.12(0-67)$ & $49.89 \pm 9.65(20-65)$ & $50.40 \pm 12.6(20-80)$ & $43.62 \pm 17.1(0-75)$ & $53.06 \pm 46.1(0-100)$ & $55.42 \pm 12.3(16-76)$ \\
\hline $4 \mathrm{kez}$ & $76.84 \pm 19.5(45-100)$ & $64.77 \pm 42.3(0-100)$ & $29.71 \pm 1.88(0-78)$ & $52.06 \pm 8.97(30-75)$ & $47.39 \pm 12.4(25-70)$ & $47.01 \pm 15.1(0-75)$ & $50.00 \pm 44.8(0-100)$ & $54.69 \pm 11.6(8-72)$ \\
\hline Diğer & $69.28 \pm 30.6(5-100)$ & $45.53 \pm 45.6(0-100)$ & $32.14 \pm 2.34(0-78)$ & $53.92 \pm 9.26(30-65)$ & $46.78 \pm 13.8(25-70)$ & $50.00 \pm 11.7(25-75)$ & $44.04 \pm 43.5(0-100)$ & $54.00 \pm 11.4(24-72)$ \\
\hline \multicolumn{9}{|l|}{ Test ve p değeri } \\
\hline$\underline{\mathrm{KW} ; \mathrm{p}}$ & $3.427 ; 0.489$ & $8.191 ; 0.085$ & $10.457 ; .033$ & $4.737 ; 0.315$ & $3.031 ; 0.553$ & $1.243 ; 0.871$ & $4.814 ; 0.307$ & $6.758 ; 0.149$ \\
\hline \multicolumn{9}{|l|}{ Çocuğun gece uykusu düzeni } \\
\hline Düzenli & $80.35 \pm 21.1(0-100)$ & $72.81 \pm 41.2(0-100)$ & $21.25 \pm 1.79(0-67)$ & $50.99 \pm 9.44(20-70)$ & $49.44 \pm 12.9(20-75)$ & $45.53 \pm 15.2(0-75)$ & $56.34 \pm 44.1(0-100)$ & $55.26 \pm 10.0(16-72)$ \\
\hline Düzensiz & $64.93 \pm 24.7(0-100)$ & $47.97 \pm 43.9(0-100)$ & $32.28 \pm 2.27(0-78)$ & $54.05 \pm 8.78(30-75)$ & $47.29 \pm 12.0(25-80)$ & $48.31 \pm 14.0(0-88)$ & $45.49 \pm 43.2(0-100)$ & $52.16 \pm 11.5(8-76)$ \\
\hline \multicolumn{9}{|l|}{ Test ve p değeri } \\
\hline$\underline{\mathrm{U} ; \mathrm{p}}$ & $-4.412 ; 0.000$ & $-4.097 ; 0.000$ & $-3.245 ; 0.001$ & $-1.998 ; 0.046$ & $-1.489 ; 0.136$ & $-0.978 ; 0.328$ & $-1.555 ; 0.120$ & $-2.371 ; 0.018$ \\
\hline \multirow{2}{*}{\multicolumn{9}{|c|}{ Çocuğun gece uykusunun ne zaman düzene gi }} \\
\hline & & & & & & & & \\
\hline Birinc & $67.02 \pm 25.2(5-100)$ & $54.72 \pm 45.3(0-100)$ & $29.42 \pm 2.22(0-78)$ & $54.18 \pm 8.31(30-75)$ & $47.09 \pm 11.7(25-70)$ & $47.63 \pm 13.1(0-88)$ & $46.84 \pm 43.4(0-100)$ & $52.10 \pm 12.0(8-76)$ \\
\hline İkinci a & $78.25 \pm 23.9(0-100)$ & $61.25 \pm 45.9(0-100)$ & $25.83 \pm 1.8$ & $53.50 \pm 8.71(35-70)$ & $51.12 \pm 13$. & $48.75 \pm 12.2(25-75)$ & $54.16 \pm 46.3(0-100)$ & $57.90 \pm 8.59(28-72)$ \\
\hline dan itibaren & $80.27 \pm 21.4(30-100)$ & $74.30 \pm 40.3(0-100)$ & $0-67)$ & $48.47 \pm 10.6(20-65)$ & $51.25 \pm$ & $42.70 \pm$ & $50.00 \pm 45.4(0-100)$ & $54.77 \pm 11.1(16-68)$ \\
\hline Diğer & $78.19 \pm 19.3(50-100)$ & $75.00 \pm 40.5(0-100)$ & $22.70 \pm 2.02(0-67)$ & $49.13 \pm 8.20(30-60)$ & $48.69 \pm 10.3(25-65)$ & $45.10 \pm 18.3(0-75)$ & $44.50 \pm 44.5(0-100)$ & $55.47 \pm 10.8(16-68)$ \\
\hline Test ve $p$ değeri & $79.07 \pm 20.9(45-100)$ & $67.59 \pm 45.8(0-100)$ & $21.81 \pm 1.78(0-67)$ & $51.85 \pm 10.1(30-65)$ & $45.74 \pm 12.9(20-60)$ & $46.75 \pm 18.5(0-75)$ & $39.74 \pm 39.7(0-100)$ & $52.00 \pm 7.01(40-60)$ \\
\hline $\mathrm{KW} ; \mathrm{p}$ & $11.400 ; 0.022$ & $7.978 ; 0.092$ & $5.465 ; 0.243$ & $10.625 ; 0.031$ & $5.679 ; 0.224$ & $2.502 ; 0.644$ & $3.433 ; 0.488$ & $12.855 ; 0.012$ \\
\hline \multicolumn{9}{|l|}{ Annelerin Çocuğunu Uyutma şekli } \\
\hline Emzirerek & ( & f & 8) & 5) & ) & 45 & 45 & 2) \\
\hline Ayağınızda sallay & $79.62 \pm 20.0(45-100)$ & $75.74 \pm 39.8(0-100)$ & $19.73 \pm 1.80(0-67)$ & $54.32 \pm 8$ & $49.25 \pm 1$ & $44.02 \pm$ & $61.19 \pm 44.7(0-100)$ & $53.97 \pm 9.60(32-76)$ \\
\hline Kucakt & $79.58 \pm 17.1(55-100)$ & $66.66 \pm 44.3(0-100)$ & $3(0-67)$ & $47.91 \pm 9$ & $48.33 \pm 1$ & $52.08 \pm$ & $72.22 \pm 37.1(0-100)$ & $50.33 \pm 18.3(16-72)$ \\
\hline Yatakta & $75.00 \pm 23.7(30-100)$ & $75.00 \pm 40.0(0-100)$ & $29.16 \pm 2.29(11-78)$ & $47.50 \pm 8.45(30-55)$ & $45.62 \pm 15.4(25-65)$ & $51.56 \pm 8.01(37-63)$ & $16.66 \pm 35.6(0-100)$ & $49.00 \pm 9.73(32-60)$ \\
\hline pp kendi başına bırakarak & $76.36 \pm 21.8(45-100)$ & $62.12 \pm 42.9(0-100)$ & $26.93 \pm 2.11(0-78)$ & $50.90 \pm 10.8(35-70)$ & $47.27 \pm 11.7($ & $47.34 \pm 14.5(0-75)$ & $57.57 \pm 42.7(0-100)$ & $51.03 \pm 12.2(8-64)$ \\
\hline Beşiğini sallayarak & $81.76 \pm 18.7(50-100)$ & $54.41 \pm 46.1(0-100)$ & $33.33 \pm 2.00(0-67)$ & $50.88 \pm 7.95(35-60)$ & $47.94 \pm 12.9(30-70)$ & $51.47 \pm 14.4(25-75)$ & $29.41 \pm 37.0(0-100)$ & $58.58 \pm 5.99(48-64)$ \\
\hline Diğer & $73.75 \pm 13.1(55-85)$ & $62.50 \pm 47.8(0-100)$ & $16.66 \pm 2.12(0-45)$ & $50.00 \pm 7.07(40-55)$ & $41.25 \pm 4.78(35-45)$ & $43.75 \pm 12.5(25-50)$ & $75.00 \pm 31.9(33-100)$ & $52.00 \pm 10.8(44-68)$ \\
\hline \multicolumn{9}{|c|}{ (1) } \\
\hline $\mathrm{KW} ; \mathrm{p}$ & $10.858 ; 0.093$ & $12.029 ; 0.061$ & $9.114 ; 0.167$ & $11.669 ; 0.070$ & $3.328 ; 0.767$ & $7.014 ; 0.320$ & $17.781 ; 0.007$ & $11.456 ; 0.075$ \\
\hline \multicolumn{9}{|l|}{ 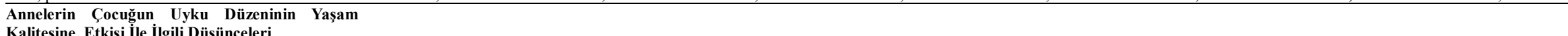 } \\
\hline Yaşam kalitemi etkilemiyor & 8 & & & & & & & $3-72)$ \\
\hline Yaşam kalitemi olumsuz etkiliyor & $62.50 \pm 22.6(0-100)$ & $47.01 \pm 44.4(0-100)$ & $32.00 \pm 2.01(0-78)$ & $53.85 \pm 8.45(30-75)$ & $47.06 \pm 11.8(20-70)$ & $46.60 \pm 15.6(0-88)$ & $39.85 \pm 43.7(0-100)$ & $54.47 \pm 10.5(24-76)$ \\
\hline \multicolumn{9}{|l|}{ Test ve } \\
\hline$\underline{\mathrm{U} ; \mathrm{p}}$ & $-4.314 ; 0.000$ & $-4.984 ; 0.000$ & $-4.286 ; 0.000$ & $-2.406 ; 0.016$ & $-1.809 ; 0.070$ & $-0.248 ; 0.804$ & $-3.615 ; 0.000$ & $-0.366 ; 0.715$ \\
\hline
\end{tabular}

Page | 311

www.iiste.org 


\section{Sonuç ve Öneriler}

Çalışmada annelerin yaşam kalitelerinin farklı alanlarda anne yaşı arttıkça ve eğitim düzeyi azaldıkça, çocuğun yaşı azaldıkça, ailedeki çocuk sayısı arttıkça, günlük ortalama uyku süresinin azalması, çocukta sağlık probleminin olması ile ve çocuğun düzenli uykuya sahip olmamasına ile düşmektedir. Ayrıca annelerin çocuklarını ebeveyn katılımını gerektirecek (emzirerek ve sallayarak) girişimler ile uyutan ve çocuğun uyku düzeninin yaşam kalitesini etkilediğini düşünen annelerin yaşam kalitesinin daha düşük olduğu belirlenmiştir.

$\mathrm{Bu}$ bulgular doğrultusunda 0-2 yaş döneminde çocukların uyku alışkanlıklarının annelerin tutum ve davranışlarından etkilendiği vurgulanmaktadır. Özellikle küçük çocuklarda uyku ile ilgili doğru davranışlar sergilenerek annenin yaşam kalitesini düşürmeyecek uyku alışkanlıkları kazanmaların sağlanabilmektedir. Bu konuda annelere farkındalık kazandırılması amacıyla annelere çocukların uyku alışkanlıklarını düzenlemeleri ve rutinlerinin oluşturulmasına yönelik eğitimler verilmesi önerilmektedir.

\section{Kaynaklar}

Ahn, Y. M., Williamson, A. A., Seo, H. J., Sadeh, A., \& Mindell, J. A. (2016). Sleep patterns among South Korean infants and toddlers: Global comparison. J Korean Med Sci, 31, 261-269. http://doi.org/10.3346/jkms.2016.31.2.261

Ceylan, Ş., Kahraman, Ö. G., \& Ülker, P. (2016). Mothers' point of view for early childhood period. Journal of the Human and Social Sciences Researches, 5(5), 1333-1356.

Chung, S., \& An, H. (2014). Cultural Issues of Co-Sleeping in Korea. Sleep Med Res, 5(2), 37-42. http://doi.org/2014.5.2.37

Cohenca-Shiby, D., \& Schonbach-Medina, S. (2013). The relationship between mothers' attachment orientations and their infants' sleep patterns. Child Development Research, 2013, 1-8. http://doi.org/10.1155/2013/324217

Erdoğan, Ç., \& Turan, T. (2018). Mothers' preferences for safe sleep in newborns. Journal of Turkish Sleep Medicine, 5, 58-61.

Figueiredo, B., Dias, C. C., Pinto, T. M., \& Field, T. (2017). Exclusive breastfeeding at three months and infant sleep-wake behaviors at two weeks, three and six months. Infant Behavior and Development, 49(2017), 62-69. http://doi.org/10.1016/j.infbeh.2017.06.006

Gözün Kahraman, Ö., \& Ceylan, Ş. (2018). Determining the sleeping habits of toddlers aged 0-3. Journal of History Culture and Art Research, 7(3), 607-620. http://doi.org/10.7596/taksad.v7i3.1635

Güler, S., Avc1, S., Yiğit, F., \& Ortabağ, T. (2018). 0-12 aylık bebeği olan annelerin bebek bakımında başvurdukları geleneksel uygulamalar ve tutumlarının belirlenmesi. KASHED, 4(1), 35-50.

Kostak, M. A., Kocaaslan, E. N., Bilsel, A., \& Mutlu, A. (2016). Determination of sleep habits in children aged 3-6 years. HSP, 3(1), 123-132.

Lélis, A. L. P. de A., Cipriano, M. A. B., Cardoso, M. V. L. M. L., Lima, F. E. T., \& Araújo, T. L. de. (2014). Influence of the family context on sleep disorders in children. Rev Rene., 15(2), 343-353. http://doi.org/10.15253/2175-6783.2014000200020

Magee, C. A., Caputi, P., \& Iverson, D. C. (2012). Are parents' working patterns associated with their child's sleep? An analysis of dual-parent families in Australia. Sleep and Biological Rhythms, 10(2), 100-108. http://doi.org/10.1111/j.1479-8425.2011.00530.x

Martín Martín, R., Sánchez Bayle, M., \& Francisco, C. T. de. (2017). Co-sleeping in our environment: case-control study in paediatric primary care offices. Rev Pediatr Aten Primaria, 19, 15-21. Retrieved from http://www.pap.es/files/1116-2253-pdf/RPAP_73_Colecho_estudio.pdf

Martins, R. M. A., Oliveira, J. R. A., Salgado, C. C. G., Marques, B. L. S., Oliveira, L. C. F., Oliveira, 
G. R., ... Ferreira, R. T. (2018). Sleep habits in infants: the role of maternal education. Sleep Medicine, 52(December), 138-144. http://doi.org/10.1016/j.sleep.2018.08.020

Mindell, J. A., Sadeh, A., Kohyama, J., \& How, T. H. (2010). Parental behaviors and sleep outcomes in infants and toddlers: A cross-cultural comparison. Sleep Medicine, 11(4), 393-399. http://doi.org/10.1016/j.sleep.2009.11.011

Mindell, J. A., Sadeh, A., Kwon, R., \& Goh, D. Y. T. (2015). Relationship between child and maternal sleep: a developmental and cross-cultural comparison. Journal of Pediatric Psychology, 40(7), 689-696. http://doi.org/10.1093/jpepsy/jsv008

Özkan, E. A. (2018). Growing up in sleep. Bozok Med J, 8(Özel Sayı), 75-78.

Richardson, B. (2013). Exploring mother-infant bedsharing through a cross-cultural lens. Journal of the Motherhood Initative, 4(2), 120-129.

Syed, M., \& Mclean, K. C. (2017). Erikson's theory of psychosocial development. PsyArXiv. http://doi.org/10.31234/osf.io/zf35d

T.C. Çalışma ve Sosyal Güvenlik Bakanlığı... (2016). Analık izni veya ücretsiz izin sonrası yapılacak kısmi süreli çalışmalar hakkında yönetmelik.

Tuaç, P. (2017). Analık Hâlinde İş ve Sosyal Güvenlik Hukukundan Doğan Haklar - 6663 Sayılı Kanun ile Getirilen Yenilikler-. Dokuz Eylül Üniversitesi İktisadi ve İdari Bilimler Fakültesi Dergisi, 32(1), 201-241.

Waring, G., Kirk, S., \& Fallon, D. (2019). The impact of chronic non-specific cough on children and their families: a narrative literature review. $J$ Child Health Care, 1-18. http://doi.org/10.1177/1367493518814925 